\title{
PENGARUH STRATEGI PEMBELAJARAN DAN GAYA BELAJAR TERHADAP HASIL BELAJAR MENGGAMBAR TEKNIK
}

\author{
Novidawaty Tambunan \\ Guru SMK Negeri 2 Medan \\ novidawatytambunan@gmail.com
}

\begin{abstract}
Abstrak: Penelitian ini bertujuan untuk mengetahui: (1) Perbedaan hasil belajar Menggambar teknik 1 antara siswa yang diajar dengan strategi pembelajaran Mind Map dan strategi pembelajaran ekspositori, (2) Perbedaan hasil belajar Menggambar teknik 1 antara siswa yang memiliki gaya belajar visual dengan kinestetik, (3) interaksi antara strategi pembelajaran dan gaya belajar terhadap hasil belajar Menggambar teknik 1. Metode penelitian yang menggunakan metode quasi eksperimen dengan desain penelitian faktorial $2 x 2$. Teknik analisis data menggunakan ANAVA dua jalur pada taraf signifikansi $\alpha=0,05$. Hasil penelitian menunjukkan bahwa: (1) hasil belajar Menggambar teknik 1 siswa yang diajar dengan strategi pembelajaran Mind Map, lebih tinggi dari pada strategi pembelajaran ekspositori; (2) hasil belajar Menggambar teknik 1 siswa yang memiliki gaya belajar Kinestetik lebih tinggi daripada gaya belajar Visual; (3) terdapat interaksi antara strategi pembelajaran dan gaya belajar terhadap hasil belajar Menggambar teknik 1.
\end{abstract}

Kata Kunci: strategi pembelajaran, gaya belajar, menggambar teknik

Abstract: This study aims to determine: (1) Differences in learning outcomes Drawing techniques 1 between students taught with Mind Map learning strategies and expository learning strategies, (2) Differences in learning outcomes Drawing techniques 1 between students who have visual learning styles with kinestetik, (3) interaction between learning strategy and learning style to learning result Drawing technique 1. Method research using quasi experimental method with $2 x$ factorial research designs 2. Data analysis technique using two-way ANOVA at significance level $\alpha=0,05$. The results showed that: (1) learning result Drawing technique 1 students taught by Mind Map learning strategy, higher than expository learning strategy; (2) learning outcomes Drawing techniques 1 students who have a higher learning style Kinesthetic than Visual learning style; (3) there is an interaction between learning strategies and learning styles on learning outcomes Drawing technique 1.

Keywords: learning strategy, learning style, drawing technique

\section{PENDAHULUAN}

Pendidikan mempunyai pengaruh inovatif terhadap kondisi-kondisi kemasyarakatan dalam rangka meningkatkan kualitas SDM, menuju sistem sosial yang dinamis serta modernisasi masyarakat, di tengah-tengah perkembangan dunia saat ini.

Menurut Muller (2001: 115) bahwa : "Pendidikan itu sendiri dapat meliputi pendidikan formal (sekolah), pendidikan informal (keluarga, tempat kerja, agama) dan pendidikan informal yaitu pendidikan luar sekolah yang dilembagakan (LSM, Media Massa, dan sebagainya)". Sebagai lembaga yang menyediakan tenaga-tenaga terampil di Indonesia, terdapat jalur pendidikan formal di sekolah lanjutan tingkat atas, yaitu Sekolah Menengah Kejuruan (SMK).

Gagne (1984) mengatakan belajar adalah suatu perubahan watak (disposition) dan kemampuan (capability) manusia yang berlangsung selama suatu jangka waktu dan tak sekedar menganggapnya proses pertumbuhan. Selanjutnya Gagne mengatakan belajar terjadi apabila suatu situasi stimulus bersama dengan isi ingatan mempengaruhi siswa sedemikian rupa sehingga perbuatan (performance) berubah dari waktu ke waktu selama ia mengalami situasi.

$$
\text { Selain itu Lazzader (2003:91) }
$$

menyatakan bahwa: "gambar teknik merupakan suatu sarana yang terpenting untuk melukiskan daya cipta lewat penggunaan garis, Sehingga 
melalui sebuah gambar, seseorang dapat menangkap dan memahami hal-hal yang terkandung dan direncanakan dalam gambar tersebut". Gambar merupakan suatu hasil pengekspresian ide-ide dari seseorang terhadap suatu objek yang berada di luarnya. Hasil ideide tersebut tertuang pada gambar dalam bentuk sketsa dari objek secara keseluruhan. Menggambar teknik itu sendiri adalah proses mengekspresikan ide-ide suatu objek yang telah ada ataupun sebuah rancangan yang dituangkan dalam bentuk gambar dengan mengikuti kaidah-kaidah menggambar teknik itu sendiri.

Perubahan perilaku sebagai perbuatan belajar sering disebut hasil belajar. Hasil belajar menurut Romizowski (1981) menyatakan bahwa hasil belajar diperoleh dalam bentuk pengetahuan dan keterampilan. Pengetahuan dikelompokkan kepada empat kategori yaitu fakta, konsep, prosedur dan prinsip. Fakta merupakan pengetahuan tentang objek nyata, asosiasi dari kenyataan dan informasi verbal dari suatu objek, peristiwa atau manusia. Konsep adalah pengetahuan tentang seperangkat objek konkrit atau definisi. Prosedur merupakan pengetahuan mengenai tindakan demi tindakan yang bersifat linier dalam mencapai suatu tujuan. Selanjutnya prinsip adalah pernyataan mengenai hubungan dua konsep atau lebih. Sedangkan hasil belajar dalam bentuk keterampilan dikelompokkan pada empat kategori yaitu: keterampilan kognitif, akting, reaksi dan interaksi. Keterampilan kognitif berkaitan tentang seseorang dalam menggunakan pikirannya untuk mengambil keputusan atau memecahkan masalah. Keterampilan berakting adalah keterampilan fisik atau teknik, seperti olah raga, mengajarkan sesuatu dan lain sebagainya. Keterampilan reaksi merupakan keterampilan bereaksi terhadap suatu situasi dalam artian nilai-nilai emosi dan perasaan yang biasanya disebut dengan sikap. Sedang keterampilan interaksi adalah keterampilan sesorang dalam berhubungan dengan orang lain untuk mencapai suatu tujuan seperti komunikasi, persuasi dan pendidikan.

Perubahan tingkah laku yang dapat diamati dari penampilan orang yang belajar adalah hasil belajar. Pada hakikatnya hasil belajar menunjukkan tingkat kemampuan siswa dalam mengikuti suatu proses pembelajaran. Tingkat kemampuan siswa dari hasil belajar ini dapat dilihat dari kemampuan kognitif, afektif, dan psikomotorik (Bloom, 1986). Senada dengan pendapat di atas Arikunto (2001) menyatakan bahwa hasil belajar merupakan suatu yang diperoleh dari dan sesudah kegiatan pembelajaran berlangsung. Hasil belajar ini dinyatakan dalam bentuk angka, huruf, atau kata-kata baik, sedang, dan kurang. Dari kedua pendapat di atas, dapat disebutkan bahwa hasil belajar merupakan kemampuan siswa yang indikasinya berupa penguasaan pengetahuan, perubahan sikap, dan peningkatan keterampilan yang diperoleh setelah mengikuti kegiatan belajar. Hasil belajar ini merupakan kemampuan aktual yang dapat diukur langsung melalui tes yang sesuai dengan tujuan pembelajaran.

Sehubungan dengan jenis-jenis kemampuan yang merupakan produk hasil belajar yang dikemukakan oleh Bloom di atas, Gagne (1977) mengelompokkan hasil belajar menjadi lima kategori, yaitu: keterampilan intelektual, strategi kognitif, informasi verbal, keterampilan motorik, dan sikap. Kemampuan yang dikemukakan di atas harus sesuai dengan tujuan pembelajaran yang telah ditetapkan. Tiga kategori pertama Gagne yaitu informasi verbal, keterampilan intelektual, dan strategi kognitif dapat disejajarkan dengan ranah kognitif Bloom yang telah direvisi (Anderson, dkk, 2001), yaitu pengetahuan (C1), pemahaman (C2), penerapan (C3), analisis (C4), evaluasi (C5), dan kreativitas (C6). Hasil belajar dalam penelitian ini mencakup kelima aspek kognitif yang dikemukakan Anderson dkk (2001) di atas, kecuali kreativitas (C6).

Reigeluth (1983) menyatakan bahwa hasil belajar dipengaruhi oleh interaksi antara metode pengajaran dan kondisi pengajaran. Hal-hal yang termasuk metode pengajaran antara lain strategi pengorganisasian, strategi pengelolaan pembelajaran dan penyampaian. Selanjutnya hal-hal yang termasuk kondisi pengajaran adalah karakteristik siswa, karakteristik isi pengajaran, kendala pengajaran, dan berbagai kondisi lain dalam proses pembelajaran. Sedangkan menurut Bloom (1986), ada dua faktor yang sangat berpengaruh terhadap hasil belajar siswa, yaitu kualitas pembelajaran dan karakteristik siswa. Dalam proses penilaian belajar yang berhubungan dengan aspek kognitif biasanya diukur dengan menggunakan tes, sedangkan penilaian hasil belajar yang berhubungan dengan aspek afektif dan keterampilan biasanya diukur dengan alat ukur yang 
dikategorikan dengan non tes (Nasution dan Suryanto, 2002)

Karakteristik mata pelajaran

Menggambar Teknik yang sangat berketerkaitan dengan kemampuan berfikir logis dan kreatif, menuntut suatu pola metode belajar yang dapat menyeimbangkan antara fungsi otak kiri (berfikir logis) dan fungsi otak kanan (aktivitas kreatif) siswa. Ada beberapa strategi belajar yang dapat dipilih dalam meningkatkan motivasi siswa dalam belajar, namun pada kesempatan ini penulis ingin meneliti tentang pembelajaran yang menyenangkan bagi siswa atau yang biasa dikenal dengan istilah Quantum Learning dengan strategi belajar Mind Map.

Strategi pembelajaran adalah suatu kegiatan pembelajaran yang harus dikerjakan guru dan siswa agar tujuan pembelajaran dapat dicapai secara efektif dan efisien. Bahwa dalam strategi pembelajaran terkandung makna perencanaan. Artinya, bahwa strategi pada dasarnya masih bersifat konseptual tentang keputusan-keputusan yang akan diambil dalam suatu pelaksanaan pembelajaran." Akhmad Sudrajat (2008).

Menurut Romizowski (1981) strategi pembelajaran merupakan suatu pendekatan yang dibedakan menjadi dua strategi dasar, yaitu ekspositori (penjelasan) dan inquiri atau diskoveri (penemuan). Kedua strategi ini dapat dipandang sebagai dua ujung yang sejalan dalam suatu kontinum strategi, hal ini erat kaitannya dengan pendekatan deduktif di mana strategi ini dimulai dengan penyajian informasi mengenai prinsip atau kaidah kemudian diikuti dengan tes penguasaan, penerapan dalam bentuk contoh dan penerapan pada situasi tertentu. Sedangkan inquiri atau diskoveri didasarkan pada teori belajar pengalaman yang disebut juga teori belajar pengalaman.

Dick and Carey (2005) menyatakan bahwa strategi pembelajaran merupakan komponen umum dari bahan pembelajaran dan prosedur yang akan digunakan untuk menghasilkan suatu hasil belajar pada siswa, yang berkenaan dengan strategi pembelajaran untuk menyampaikan materi secara sistematik sehingga kemampuan yang diharapkan dapat dikuasai secara efektif dan efisien. Lebih lanjut Carey (2005) menjelaskan bahwa ada 5 (lima) komponen strategi pembelajaran: (1) prainstruksional, yang meliputi: memotivasi siswa, deskripsi materi, dan analisis perilaku awal; (2) penyajian informasi, yang meliputi: penjelasan tujuan pembelajaran, uraian isi materi dan contoh; (3) partisipasi siswa, yang meliputi: latihan dan umpan balik; (4) penilaian (tes), yang meliputi: tes perilaku awal, pretes, dan protes; dan (5) tindak lanjut, yang meliputi: bantuan kesan untuk ingatan dan pertimbangan.

Sementara itu, Gerlach dan Erly (1980) mendefinisikan bahwa strategi pembelajaran merupakan semua metode mengajar yang dapat dipakai guru untuk menyampaikan materi, mulai dari ekspositori sampai ke metode discovery dan tugas guru adalah memilih strategi pembelajaran tersebut untuk menyampaikan materi. Sementara itu, Uno (2008: 45) berpendapat bahwa strategi pembelajaran merupakan hal yang perlu diperhatikan guru dalam proses pembelajaran. Paling tidak ada tiga jenis strategi pembelajaran, yakni: (1) strategi pengorganisasian pembelajaran, (2) strategi penyampaian pembelajaran, dan (3) strategi pengelolaan pembelajaran.

Mind Map menurut Sutanto (2008: 16) adalah suatu teknik grafis yang memungkinkan kita untuk mengeksplorasi seluruh kemampuan otak kita untuk keperluan berfikir dan belajar.

Menurut Sutanto (2008: 16) Otak manusia secara fungsional dibagi ke dalam dua bagian yaitu otak kanan dan otak kiri. Otak kiri akan berkaitan dengan kata, angka, analisa, logika, urutan, hitungan dan detil. Sedangkan otak kanan berkaitan dengan gambar, warna, irama, gestalt dimensi, imajinasi, dan melamun.

Sedangkan menurut Sutanto (2008: 2): "Whole Brain Thinking adalah suatu terobosan cara berpikir dengan memanfaatkan dua belahan otak secara sinergis. Mind mapping atau pemetaan pikiran merupakan salah satu teknik mencatat tinggi." Informasi berupa materi pelajaran yang diterima siswa dapat diingat dengan bantuan catatan. Peta pikiran merupakan bentuk catatan yang tidak monoton karena Mind mapping memadukan fungsi kerja otak secara bersamaan dan saling berkaitan satu sama lain. Sehingga akan terjadi keseimbangan kerja kedua belahan otak. Otak dapat menerima informasi berupa gambar, simbol, citra, musik dan lain-lain yang berhubungan dengan fungsi kerja otak kanan.

Sanjaya (2009:179) mengemukakan bahwa strategi pembelajaran Ekspositori adalah strategi pembelajaran yang menekankan kepada proses penyampaian materi secara verbal dari seorang guru kepada sekelompok 
siswa dengan maksud agar siswa dapat menguasai materi pelajaran secara optimal.

Killen dalam Sanjaya (2009) menamakan strategi Ekspositori ini dengan istilah strategi pembelajaran langsung (direct instruction). Oleh karena strategi ekspositori lebih menekankan kepada proses bertutur, maka sering juga dinamakan dengan istilah strategi "chalk and talk".

Kemudian De Porter (2008 :110) mengatakan gaya belajar merupakan cara yang cenderung dipilih seseorang untuk menerima informasi dari lingkungan dan memproses informasi tersebut. Dalam hal belajar, masingmasing individu memiliki kelebihan dan kekurangan dalam menyerap pelajaran yang diberikan. Oleh karena itu dalam dunia pendidikan dikenal berbagai metode yang dapat dipergunakan guru untuk dapat memenuhi tuntutan perbedaan individu tersebut. Guru membutuhkan rancangan desain pembelajaran untuk menjembatani hubungan antara siswa dengan guru sesuai dengan gaya belajarnya.

Olivia (2008:2) mengatakan bahwa tidak ada gaya belajar yang lebih baik dari yang lain, karena ketiga gaya belajar ini dimiliki oleh setiap orang. Hanya saja ada salah satu gaya belajar yang lebih dominan pada diri kita. Jadi, bila seseorang belajar sesuai dengan gaya belajarnya yang dominan, pelajaran akan lebih mudah diterima dan kemungkinan suksesnya juga lebih tinggi.

Menurut DePorter (2007:165) ada beberapa gaya belajar lainnya yang bisa dipilih untuk belajar secara efektif. Beberapa gaya belajar yang mungkin terdapat pada anak didik yakni gaya belajar Auditorial, gaya belajar Kinestetik, dan gaya belajar Visual.

Rumusan masalah pada penelitian ini adalah: (1) Apakah hasil belajar siswa yang menggunakan strategi pembelajaran Mind Map lebih tinggi dari hasil belajar siswa yang diajar dengan strategi pembelajaran ekspositori?, (2) Apakah hasil belajar siswa yang memiliki gaya belajar Kinestetik lebih tinggi dari pada hasil belajar siswa yang memiliki gaya belajar Visual dalam mata pelajaran Menggambar Teknik 1?, dan (3) Apakah terdapat interaksi antara strategi pembelajaran dengan dengan gaya belajar dalam mempengaruhi hasil belajar Menggambar Teknik 1?

\section{METODE}

Penelitian in dilaksanakan di SMK Negeri 2 dan SMK Negeri 5 Medan . Populasi dalam penelitian ini adalah siswa-siswi SMK Negeri 2 Medan kelas X Jurusan dan siswasiswi SMK Negeri 5 Medan kelas X Jurusan Bangunan yang terdiri dari empat kelas yaitu SMK Negeri 2 Medan kelas X Jurusan Bangunan dengan jumlah siswa 36 orang dan SMK Negeri 5 Medan kelas X Jurusan Bangunan dengan jumlah siswa 40 orang. Teknik pengambilan sampel dilakukan dengan teknik cluster random sampling, selanjutnya melalui pengundian maka SMK Negeri 2 Medan kelas X Jurusan Bangunan sebagai kelas yang diberi perlakuan dengan strategi pembelajaran Mind Map (kelas eksprimen) dan Negeri 5 Medan kelas X Jurusan Bangunan terpilih sebagai kelas yang diberi perlakuan dengan strategi pembelajaran ekspositori (kelas kontrol). Sebelum dilakukan eksperimen, kedua kelas sampel terlebih dahulu diberi tes untuk mengetahui gaya belajar siswa. Gaya belajar dikategorikan atas gaya belajar kinestetik dan gaya belajar visual.

Penelitian ini menggunakan metode eksperimental semu (quasi-experimental design) dengan melakukan eksperimen di dalam kelas yang sudah tersedia sebagaimana adanya, tanpa melakukan perubahan situasi kelas dan jadwal pembelajaran (kelas yang intaks). Perlakuan dilaksanakan pada pembelajaran Mengambar teknik dengan menggunakan strategi pembelajaran Mind Map yang dibandingkan dengan strategi pembelajaran ekspositori dan dilaksanakan pada kelas perlakuan yang telah ditetapkan. Pada masingmasing kelas terdapat siswa yang memiliki gaya belajar kinestetik dan gaya belajar visual berdasarkan hasil analisis skor tes gaya belajar menurut De Porter (2008) yang telah baku dan disusun dengan menggunakan indikatorindikator yang telah standar. Guru yang ditetapkan untuk melakukan pembelajaran dengan strategi pembelajaran berbasis masalah maupun ekspositori diberikan petunjuk khusus mengenai cara dan langkah-langkah dalam penyajian materi pelajaran.

Desain penelitian yang digunakan adalah desain faktorial $2 \times 2$, seperti terlihat pada Tabel 1. yang mengelompokkan strategi Mind Map dengan strategi pembelajaran ekspositori terhadap gaya belajar visual dan gaya belajar kinestetik. 
Tabel 1. Desain Faktorial $2 \times 2$

\begin{tabular}{|l|c|c|}
\hline \multicolumn{1}{|c|}{ Gaya belajar $(\mathbf{B})$} & \multicolumn{2}{|c|}{ Strategi Pembelajaran (A) } \\
\cline { 2 - 3 } & Mind Map $\left(\mathbf{A}_{1}\right)$ & Ekspositori $\left(\mathrm{A}_{2}\right)$ \\
\hline Kinestetik $\left(\mathbf{B}_{1}\right)$ & $\mathrm{A}_{1} \mathrm{~B}_{1}$ & $\mathrm{~A}_{2} \mathrm{~B}_{1}$ \\
\hline Visual $\left(\mathrm{B}_{2}\right)$ & $\mathrm{A}_{1} \mathrm{~B}_{2}$ & $\mathrm{~A}_{2} \mathrm{~B}_{2}$ \\
\hline
\end{tabular}

Teknik analisis data dalam penelitian ini menggunakan analisis deskriptif dan analisis inferensial. Teknik analisis deskriptif dimaksudkan untuk mendeskripsikan data penelitian meliputi mean, median, standard deviasi dan kecenderungan data.

Data yang telah diperoleh selanjutnya disajikan dalam bentuk tabel distribusi frekuensi dan histogram. Teknik analisis inferensial digunakan untuk menguji hipotesis penelitian dengan menggunakan teknik analisis varians (ANAVA) dua jalur. Untuk menggunakan ANAVA dua jalur perlu dipenuhi beberapa syarat yaitu: 1) data yang digunakan harus berdistribusi normal, untuk menguji normalitas data digunakan uji Liliefors, dan 2) data harus memiliki varians populasi homogen, untuk menguji homogenitas varians digunakan uji $\mathrm{F}$ (Fisher) dan

Rumusan hipotesis statistik dalam penelitian ini adalah sebagai berikut:

a. Hipotesis pertama :

$$
\begin{aligned}
& \text { Ho: } \mu_{A 1} \leq \mu_{A 2} \\
& \text { H1: } \mu_{A 1}>\mu_{A 2}
\end{aligned}
$$

b. Hipotesis kedua :

$$
\begin{aligned}
& \text { Ho : } \mu_{B 1} \leq \mu_{B 2} \\
& \text { H1 : } \mu_{B 1}>\mu_{B 2}
\end{aligned}
$$

c. Hipotesis ketiga :

Ho : $\mathrm{A} \times \mathrm{B}=0$

$\mathrm{H} 1: \mathrm{A} \times \mathrm{B} \neq 0$

\section{HASIL PENELITIAN}

Pengujian hipotesis dilakukan untuk membuktikan kebenaran hipotesis yang telah ditetapkan sehingga diperoleh data apakah hipotesis yang dirancang dalam sebuah penelitian ditolak atau diterima. Untuk keperluan pengujian hipotesis dengan menggunakan teknik analisis varian dua jalur (ANAVA) faktorial $2 \times 2$ dan kemudian dilanjutkan dengan uji lanjut dengan menggunakan uji Scheffe maupun uji Tuickey, diperlukan harga rata-rata tiap kelompok perlukan sebagai sumber data penelitian, berikut ini disajikan rangkuman data hasil belajar menggambar teknik 1 siswa sebagai sumber pengolahan data untuk pengujian hipotesis. Rangkuman data tersebut dapat

\begin{tabular}{|c|c|c|c|c|}
\hline \multirow{2}{*}{\multicolumn{2}{|c|}{$\begin{array}{l}\text { RINGKASAN } \\
\text { DATA }\end{array}$}} & \multicolumn{2}{|c|}{ STRATEGI PEMBELAJARAN } & \multirow{2}{*}{ Total } \\
\hline & & Mind Map (SPMM) & Ekspositori (SE) & \\
\hline \multirow{2}{*}{$\begin{array}{l}\text { Gaya } \\
\text { Belajar }\end{array}$} & Kinestetik & $\begin{array}{l}\mathrm{n}_{1}=21 \\
\sum \mathrm{X}_{1}=526 \\
\sum \mathrm{X}^{2}{ }_{1}=13254 \\
\overline{\mathrm{X}}_{1}=25,05 \\
\mathrm{~s}^{2}{ }_{1}=4,35\end{array}$ & $\begin{array}{l}\mathrm{n}_{3}=23 \\
\sum \mathrm{X}_{3}=487 \\
\sum \mathrm{X}_{3}=10493 \\
\bar{X}_{3}=22,58 \\
\mathrm{~S}^{2}{ }_{3}=6,98\end{array}$ & $\begin{array}{l}\mathrm{N}_{1,3}=44 \\
\sum \mathrm{X}_{1,3}=1013 \\
\sum \mathrm{X}_{1,3}=18978 \\
\bar{X}_{1,3}=23,02 \\
\mathrm{~s}_{1,3}^{2}=10,20\end{array}$ \\
\hline & Visual & $\begin{array}{l}\mathrm{n}_{2}=15 \\
\sum \mathrm{X}_{2}=290 \\
\sum \mathrm{X}^{2}{ }_{2}=5698 \\
\overline{\mathrm{X}}_{2}=19,33 \\
\mathrm{~s}^{2}{ }_{2}=5,98\end{array}$ & $\begin{array}{l}\mathrm{n}_{4}=17 \\
\sum \mathrm{X}_{4}=367 \\
\sum \mathrm{X}^{2}{ }_{4}=8043 \\
\bar{X}_{4}=21,20 \\
\mathrm{~S}_{4}{ }_{4}=7,38\end{array}$ & $\begin{array}{l}\mathrm{N}_{2,4}=32 \\
\sum \mathrm{X}_{2,4}=684 \\
\sum \mathrm{X}_{2,4}=14470 \\
\bar{X}_{2,4}=20,72 \\
\mathrm{~s}_{2,4}^{2}=8,77\end{array}$ \\
\hline \multicolumn{2}{|l|}{ Total } & $\begin{array}{l}\mathrm{N}_{1,2}=36 \\
\sum \mathrm{P}_{1,2}=830 \\
\sum \mathrm{X}_{1,2}^{2}=19538 \\
\bar{X}_{1,2}=22,55 \\
\mathrm{~s}^{2}{ }_{1,2}=13,21\end{array}$ & $\begin{array}{l}\mathrm{N}_{3,4}=40 \\
\sum \mathrm{P}_{3,4}=873 \\
\sum \mathrm{X}_{3,4}^{2}=19301 \\
\bar{X}_{3,4}=21,54 \\
\mathrm{~s}_{3,4}^{2}=7,36\end{array}$ & $\begin{array}{l}\mathrm{N}_{\mathrm{g}}=76 \\
\sum \mathrm{X}_{\mathrm{g}}=1672 \\
\sum \mathrm{X}_{\mathrm{g}}^{2}=37569 \\
\bar{X}_{\mathrm{g}}=22,00 \\
\mathrm{~s}_{\mathrm{g}}^{2}=10,46\end{array}$ \\
\hline
\end{tabular}
dilihat pada Tabel 2 dengan menggunakan analisis deskriptif.

Tabel 2. Rangkuman Data Hasil Perhitungan Analisis Deskriptif. 
Setelah data tabel 2 diolah dengan ANAVA 2 jalur faktorial 2 × 2, maka diperoleh hasil analisis seperti ditunjukkan pada Tabel 3.

Tabel 3. Ringkasan Perhitungan ANAVA Faktorial 2x2

\begin{tabular}{|l|c|c|c|c|c|c|}
\hline \multicolumn{1}{|c|}{ Sumber Varians } & $\mathbf{J K}$ & $\mathbf{d k}$ & $\mathbf{K T}$ & $\mathbf{F}_{\text {hitung }}$ & $\begin{array}{c}\mathbf{F}_{\text {tabel }} \\
(\mathbf{\alpha = 0 , 0 5})\end{array}$ & Ket. \\
\hline Strategi & 37.48 & 1 & 37.48 & 5.72 & & Signifikan \\
Gaya Belajar & 34.03 & 1 & 34.03 & 5.19 & 3,97 & Signifikan \\
Interaksi & 241.8 & 1 & 241.8 & 36.91 & & Signifikan \\
\hline Dalam kelompok (galat) & 313.31 & 72 & 5.74 & & & \\
Total & 678.4 & 75 & & & & \\
\hline
\end{tabular}

Pada tabel ringkasan ANAVA untuk strategi pembelajaran diperoleh $\mathrm{F}_{\text {hitung }}=5,72>$ $\mathrm{F}_{\text {tabel }}=3,97$, untuk gaya belajar $\mathrm{F}_{\text {hitung }}=5,19>$ $\mathrm{F}_{\text {tabel }}=3,97$ dan untuk interaksi diperoleh $\mathrm{F}_{\text {hitung }}$ $=36,91>\mathrm{F}_{\text {tabel }}=3,97$ berdasarkan data-data tersebut, dapat disimpulkan adanya interaksi antara strategi pembelajaran dengan gaya belajar yang mempengaruhi hasil belajar menggambar teknik 1 siswa.

Perbedaan Hasil Belajar Menggambar Teknik 1 Antara Siswa yang Diajar dengan Strategi Mind Map dan Strategi Pembelajaran Ekspositori

Pengujian dilakukan terhadap hipotesis statistik yang dirumuskan sebagai berikut:

$$
\begin{gathered}
H o: \mu_{P_{12}} \leq \mu_{P_{34}} \\
H a: \mu_{P_{12}}>\mu_{P_{34}}
\end{gathered}
$$

Pernyataan hipotesis tersebut adalah :

Ho $=$ Tidak terdapat perbedaan hasil belajar menggambar teknik 1 antara siswa yang diajar dengan strategi Mind Map dengan siswa yang diajar dengan strategi pembelajaran Ekspositori

$\mathrm{Ha}=$ Siswa yang diajar dengan strategi Mind Map memperoleh hasil belajar menggambar teknik 1 lebih tinggi daripada siswa yang diajar dengan strategi pembelajaran ekspositori.

Dari hasil perhitungan analisis tentang perbedaan hasil belajar menggambar teknik 1 siswa yang diajar dengan strategi Mind Map sebesar $\overline{\mathrm{X}}=22,55$ dan strategi pembelajaran ekspositori $\quad \bar{X}=21,54$, didapat hasil perhitungan $\mathrm{F}_{\mathrm{h}}$ sebesar 5,72 dan harga tabel $\mathrm{F}_{\mathrm{t}}$ adalah 3,97. Dengan demikian temuan penelitian menyimpulkan, bahwa hipotesis penelitian yang menyatakan: hasil belajar menggambar teknik 1 siswa yang diajar dengan strategi Mind Map lebih tinggi daripada hasil belajar menggambar teknik 1 siswa yang diajar dengan strategi pembelajaran ekspositori pada taraf kepercayaan $\alpha=0,05$ telah teruji kebenarannya.

\section{Perbedaan Hasil Belajar Menggambar Teknik 1 Antara Siswa dengan Gaya Belajar Kinestetik dan Gaya Belajar Visual.}

Pengujian dilakukan terhadap hipotesis statistik yang dirumuskan sebagai berikut:

$$
\text { Ho: } \mu_{P_{13}} \leq \mu_{P_{24}} ; \mathrm{Ha}: \mu_{P_{13}}>\mu_{P_{24}}
$$

Pernyataan hipotesis tersebut adalah :

$\mathrm{H}_{0}=$ Tidak Terdapat perbedaan hasil belajar menggambar teknik 1 antara siswa yang memiliki gaya belajar kinestetik dengan siswa yang memiliki gaya belajar visual

$\mathrm{Ha}=$ Hasil belajar menggambar teknik 1 siswa yang memiliki gaya belajar kinestetik lebih tinggi daripada hasil belajar menggambar teknik 1 siswa yang memiliki gaya belajar visual

Hasil perhitungan analisis varian tentang perbedaan hasil belajar menggambar teknik 1 antara siswa yang memiliki gaya belajar kinestetik dan gaya belajar visual dengan ratarata $\bar{X}=23,02$ dan $\bar{X}=20,72$. Berdasarkan Tabel 4.16 dapat dihitung $\mathrm{F}_{\mathrm{h}}=5,19$ dan harga tabel untuk $\alpha=0,05$ dengan $\mathrm{dk}$ (1) diperoleh $\mathrm{F}_{\mathrm{t}}$ $=3,97$ sehingga dapat dinyatakan $F_{h}(5,19)>F_{t}$ $(3,97)$. Dengan demikian temuan penelitian menyimpulkan hipotesis penelitian yang menyatakan: hasil belajar menggambar teknik 1 siswa yang memiliki gaya belajar kinestetik lebih tinggi daripada hasil belajar siswa yang memiliki gaya belajar visual pada taraf kepercayaan $\alpha=0,05$ telah teruji kebenarannya. 


\section{Interaksi Antara Strategi Pembelajaran dan Gaya Belajar Terhadap Hasil Belajar Menggambar Teknik 1 Siswa}

Pengujian dilakukan terhadap hipotesis statistik yang dirumuskan sebagai berikut :

Ho : Interaksi $(\mathrm{B} \times \mathrm{T})=0 \quad ; \quad$ Ha : Interaksi $(\mathrm{B} \times \mathrm{T})$

Pernyataan hipotesis tersebut adalah :

Ho = Tidak terdapat interaksi antara strategi pembelajaran dan gaya belajar terhadap hasil belajar menggambar teknik 1 siswa.

$\mathrm{Ha}=$ Terdapat interaksi antara strategi pembelajaran dan gaya belajar terhadap hasil belajar menggambar teknik 1 siswa.

Berdasarkan hasil perhitungan ANAVA faktorial $2 \times 2$ diperoleh hasil perhitungan $F_{h}=$
36,91 dengan harga tabel $F_{t}$ untuk taraf kepercayaan $(\alpha)$ sebesar 0,05 dengan $\mathrm{dk}=1$ adalah $\mathrm{F}_{\mathrm{t}}=3,97$ sehingga dapat dinyatakan $\mathrm{F}_{\mathrm{h}}$ $(26,71)>F_{t}(3,97)$, dengan demikian dapat disimpulkan pernyataan hipotesis penelitian yang menyatakan: terdapat interaksi antara St 9 ategi pembelajaran dan gaya belajar terhadap hasil belajar menggambar teknik 1 siswa telah teruji kebenarannya pada taraf signifikan $\alpha=$ 0,05 . Data yang diperoleh dalam penelitian ini berasal dari sampel yang jumlahnya berbeda untuk setiap sel Anava. Sehingga perlu dilakukan uji Schefee, hasil pengujian dengan menggunakan uji Scheffee dapat dilihat dalam Tabel 4.

Tabel 4. Ringkasan Hasil Pengujian Dengan Menggunakan Uji Scheffe

\begin{tabular}{|l|l|l|l|l|l|}
\hline \multirow{2}{*}{ No } & \multicolumn{2}{|l|}{ Hipotesis Statistik } & \multirow{2}{*}{$\mathrm{F}_{\text {hitung }}$} & $\mathrm{F}_{\text {tabel }}$ & \\
\cline { 5 - 6 } & & $\mathrm{Ho}: \mu_{1}>\mu_{2}$ & 4,05 & 2,70 & $\alpha=1 \%$ \\
\hline 1 & $\mathrm{Ho}: \mu_{1}=\mu_{2}$ & $\mathrm{Ha}: \mu_{1}>\mu_{3}$ & 5,13 & 2,70 & 4,30 \\
\hline 2 & $\mathrm{Ho}: \mu_{1}=\mu_{3}$ & $\mathrm{Ha}: \mu_{1}>\mu_{4}$ & 2,81 & 2,70 & 4,30 \\
\hline 3 & $\mathrm{Ho}: \mu_{1}=\mu_{4}$ & $\mathrm{Ha}: \mu_{2}>\mu_{3}$ & 1,62 & 2,70 & 4,30 \\
\hline 4 & $\mathrm{Ho}: \mu_{2}=\mu_{3}$ & $\mathrm{Ha}: \mu_{2}>\mu_{4}$ & 1,05 & 2,70 & 4,30 \\
\hline 5 & $\mathrm{Ho}: \mu_{2}=\mu_{4}$ & $\mathrm{Ha}: \mu_{3}>\mu_{4}$ & 4,42 & 2,70 & 4,30 \\
\hline 6 & $\mathrm{Ho}: \mu_{3}=\mu_{4}$ & \multicolumn{3}{|l}{} \\
\hline
\end{tabular}

Dari hasil uji Scheffe diperoleh kesimpulan yaitu : (1) rata-rata skor hasil belajar menggambar teknik 1 siswa yang diajar dengan menggunakan strategi Mind Map yang memiliki gaya belajar kinestetik lebih tinggi daripada siswa yang diajar menggunakan strategi pembelajaran ekspositori yang memiliki gaya belajar kinestetik, (2) rata-rata skor hasil belajar menggambar teknik 1 siswa yang diajar dengan menggunakan strategi Mind Map yang memiliki gaya belajar kinestetik lebih tinggi dari siswa yang diajar menggunakan strategi pembelajaran ekspositori yang memiliki gaya belajar visual, (3) rata-rata skor hasil belajar menggambar teknik 1 siswa yang diajar dengan menggunakan strategi Mind Map pada siswa yang memiliki gaya belajar kinestetik lebih tinggi dari pada siswa yang diajar dengan strategi pembelajaran ekspositori dengan gaya belajar kinestetik, (4) rata-rata skor hasil belajar menggambar teknik 1 siswa yang diajar dengan menggunakan strategi pembelajaran ekspositori pada siswa yang memiliki gaya belajar kinestetik lebih tinggi rendah daripada siswa yang diajar dengan strategi pembelajaran ekspositori dengan gaya belajar visual, (5) ratarata skor hasil belajar menggambar teknik 1 siswa yang diajar dengan menggunakan strategi Mind Map pada siswa yang memiliki gaya belajar kinestetik lebih tinggi daripada siswa yang diajar dengan strategi pembelajaran ekspositori dengan gaya belajar visual, (6) ratarata skor hasil belajar menggambar teknik 1 siswa yang diajar dengan menggunakan strategi pembelajaran ekspositori pada siswa yang memiliki gaya belajar visual lebih tinggi daripada siswa yang diajar dengan strategi pembelajaran Mind Map dengan gaya belajar visual.

Hasil pengujian hipotesis di atas, menunjukkan adanya interaksi antara strategi pembelajaran dan gaya belajar terhadap hasil belajar menggambar teknik 1 . Interaksi antara strategi pembelajaran dengan gaya belajar tersebut dapat divisualisasikan dalam bentuk grafis pada gambar 1 . 


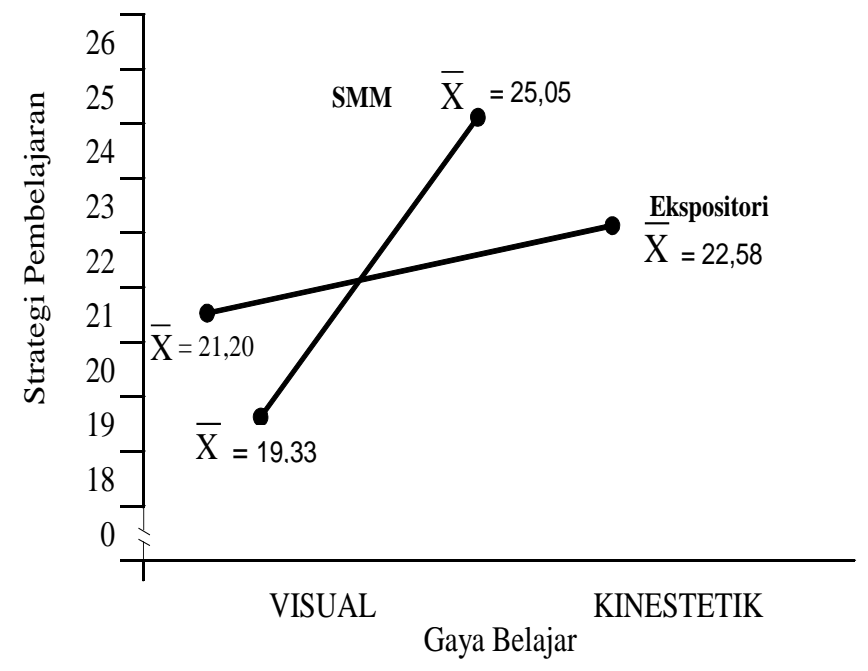

Gambar 1. Interaksi Strategi Pembelajaran dan Gaya Belajar terhadap Hasil Belajar Menggambar Teknik 1.

\section{PEMBAHASAN}

Dalam penelitian ini diperoleh data bahwa hasil belajar menggambar teknik 1 siswa lebih tinggi jika diajar dengan Strategi pembelajaran Mind Map daripada Ekspositori, namun dalam pelaksanaannya kedua jenis Strategi pembelajaran ini secara umum memiliki kelebihan dan kelemahan sesuai dengan karakteristik mata pelajaran dan karakteristik yang dimiliki siswa. Ini terbukti dari perolehan rata-rata hasil belajar siswa pada kedua kelas perlakuan terdapat perbedaan ratarata hasil belajar yang menunjukkan interaksi antara Strategi tersebut dengan karakteristik siswa. Penelitian ini membuktikan bahwa pembelajaran dengan Strategi Mind Map lebih baik jika dibandingkan dengan Strategi konvensional yang dilaksanakan selama ini di SMK Negeri 2 Medan.

Dalam pembelajaran menggambar teknik 1, siswa yang memiliki gaya belajar kinestetik biasanya akan tertantang untuk mengelola informasi yang diterima secara kreatif, dan sistematis. Sebagai pemikir realistik, siswa yang memiliki gaya belajar konkrit akan terbiasa melakukan kegiatan-kegiatan berpikir secara sistematis dan ilmiah. Dengan demikian siswa yang selalu melatih dirinya secara terus menerus akan dapat menemukan prosedur berpikir secara logis dan kreatif di dalam memecahkan persoalan-persoalan belajar, termasuk pada pelajaran menggambar teknik 1 .

Siswa yang memiliki gaya belajar kinestetik adalah siswa yang selalu dapat dengan mudah mengingat informasi yang diberikan dengan cara pendekatan pembelajaran sekongkrit mungkin. Pembelajar kinestetik akan sangat terbantu dalam belajar jika mereka dapat dilibatkan secara langsung dalam proses tersebut sehingga memberikan pemahaman dan penguatan memori kepada sipebelajar itu sendiri. Dalam strategi Mind Map tipe pembelajar kinestetik yang pada umumnya memiliki karakteristik tidak dapat diam terlalu lama dalam mendengarkan pelajaran, akan dibawa secara langsung untuk terlibat aktif dalam mengeksplorasi materi pelajaran yang mereka terima strategi belajar sekaligus menyerap informasi dalam bentuk gambar dan tulisan yang mereka buat sendiri.

Sebaliknya, Bagi siswa yang bergaya belajar visual, yang memegang peranan penting adalah mata / penglihatan ( visual ). Anak yang mempunyai gaya belajar visual harus melihat bahasa tubuh dan ekspresi muka gurunya untuk mengerti materi pelajaran. Mereka cenderung untuk duduk di depan agar dapat melihat dengan jelas. Mereka berpikir menggunakan gambar-gambar di otak mereka dan belajar lebih cepat dengan menggunakan tampilantampilan visual, seperti diagram, buku pelajaran bergambar, dan video.

Hasil analisa data penelitian melalui uji anava dua jalur diputuskan untuk menolak Ho dan menerima Ha. Hal ini menunjukkan bahwa terdapat interaksi antara strategi pembelajaran dan gaya belajar dalam mempengaruhi hasil belajar menggambar teknik 1 siswa. Hasil belajar yang optimal akan diperoleh apabila beragam perbedaan seperti 
kebiasaan, minat, gaya belajar, dan kreatifitas pada peserta didik diakomodasi oleh guru melalui pilihan strategi pembelajaran dan materi ajar yang sesuai. Pembelajaran bidang studi apapun, bisa ditingkatkan kualitasnya, apabila guru memahami karakteristik peserta didik dengan baik termasuk gaya belajarnya. Kemudian, informasi tentang peserta didik tersebut menjadi bahan pertimbangan bagi guru dalam memilih strategi dan materi ajar yang sesuai dengan keberagaman potensi peserta didik.

Oleh karena itu berdasarkan pemaparan di atas dapat dipahami bahwa interaksi antara strategi pembelajaran dengan gaya belajar dalam mempengaruhi hasil belajar menggambar teknik 1 terjadi pada siswa yang memiliki gaya belajar kinestetik. Artinya siswa dengan gaya belajar kinestetik akan memperoleh hasil belajar yang lebih tinggi dan signifikan jika dibelajarkan dengan strategi Mind Map daripada dibelajarkan dengan strategi ekspositori. Sedangkan siswa dengan gaya belajar visual meskipun cocok dibelajarkan dengan strategi pembelajaran ekspositori, namun strategi Mind Map juga memberikan hasil yang baik ketika dibelajarkan kepada mereka dengan arahan yang maksimal dari guru.

Mind merupakan gagasan berbagai imajinasi. Mind merupakan suatu keadaan yang timbul bila otak (brain) hidup da sedang bekerja (Taufik Bahaudin, 1999: 53). Lebih lanjut Bobbi de Porter dan Hernacki (199: 152) menjelaskan, peta pikiran merupakan teknik pemanfaatan keseluruhan otak dengan menggunakan citra visual dan prasarana grafis lainnya untuk membentuk suatu kesan yang lebih dalam. Peta pikiran adalah teknik meringkas bahan yang akan dipelajari dan memproyeksikan masalah yang dihadapi ke dalam bentuk peta atau teknik grafik sehingga lebih mudah memahaminya Iwan Sugiarto, 2004:75)

Pemetaan pikiran merupakan teknik visualisasi verbal ke dalam gambar. Peta pikiran sangat bermanfaat untuk memahami materi, terutama materi yang diberikan secara verbal. Peta pikiran bertujuan membuat materi pelajaran terpola secara visual dan grafis yang akhirnya dapat membantu merekam, memnperkuat, dan mengingat kemabali informasi yang telah dipelajari (Eric Jensen, 2002: 95). Sementara gaya belajar visual adalah seperti namanya, visual, yaitu gaya belajar yang memang ditumpukan pada penglihatan. Siswa dengan gaya belajar ini umumnya merasa harus melihat dulu buktinya baru bisa mempercayainya.

Ingatan, lebih ingat apa yang sudah dilakukan, daripada apa yang baru saja dilihat atau dikatakan. Lebih mengutamakan tindakan/kegiatan. Distraktibilitas, Perhatian terpecah melalui pendengaran. Pemecahan, Pemecahan masalah melalui kegiatan fisik dan aktivitas. Respons terhadap periode kosong aktivitas, Mencari kegiatan fisik bergerak. Respon untuk situasi baru, Mencoba segala sesuatu dengan meraba, merasakan dan memanipulasi. Respon terhadap seni, Respons terhadap musik melalui gerakan. Lebih memiliki patung, melukis yang melibatkan aktivitas gerakan.

Pada gaya belajar kinestetik, strategi belajar dengan pembuatan peta pikiran akan menjadi hal yang menantang dan menyenangkan untuk dicoba. Gaya belajar kinestetik yang cenderunga aktif, akan menjadikan kegiatan belajar yang melibatkan panca indra mereka khusunya tangan dan imajinasi secara seimbang. Hal ini sangat sesuai dengan kepribadian siswa dengan gaya belajar kinestetik. Sehingga dapat disimpulkan Hasil belajar menggambar teknik 1 siswa yang diajar dengan menggunakan strategi Mind Map yang memiliki gaya belajar kinestetik lebih tinggi daripada siswa yang diajar menggunakan strategi pembelajaran Mind Map yang memiliki gaya belajar visual.

Sesuai konsep di atas, bagi siswa yang memiliki gaya belajar kinestetik yang diajar dengan menggunakan strategi pembelajaran Mind Map akan dengan mudah menghubungkan materi pelajaran yang diterimanya dengan kehidupan nyata menjadikannya lebih efektif jika dibandingkan dengan gaya belajar visual karena secara keseluruhan aspek kognitif, psikomotorik, dan afektif terlibat secara langsung dalam proses pembelajarannya.

Pada straregi belajar ekspositori, Siswa cenderung membuat catatan dalam bentuk linier dan Dalam metode konvensional siswa tidak banyak terlibat baik dari segi berfikir dan bertindak. Siswa hanya menerima informasi yang telah diberikan oleh guru tanpa adanya keterlibatan kegiatan psikomotoriknya. Sementara gaya belajar visual merupakan gaya belajar yang menggunakan imajinasi sebagai sumber informasi, rapi dan teratur, berbicara 
dengan cepat, perencana dan pengatur jangka panjang, teliti terhadap detil, mengutamakan penampilan baik berpakaian atau presentasi, mengingat dengan asosiasi visual, biasanya tidak terganggu dengan keributan. Jika dihubungkan, keduanya antara gaya belajar visual dengan strategi ekspositori, terjadi proses yang saling mendukung, dimana informasi yang dibutuhkan oleh siswa dapat diperoleh dari penyajian visual yang dilakukan oleh guru dalam bentuk ceramah ataupun demonstrasi.

Sedangkan untuk strategi Mind Map yang menuntut keterlibatan siswa secara mandiri dalam proses belajar, akan menimbulkan kesulitan tersendiri bagi siswa dengan gaya belajar visual. Hal ini disebabkan karena mereka terbiasa pasif dan menerima begitu saja apa yang diberikan oleh gurunya. Mereka akan kesulitan menghubungkan materi pelajaran yang diterima dengan cara membuat rangkuman peta pikiran sacara pribadi dengan mengembangkan kreatifitas mereka. Sehingga Hasil belajar menggambar teknik 1 siswa yang diajar dengan menggunakan strategi ekspositori yang memiliki gaya belajar visual lebih tinggi daripada siswa yang diajar menggunakan strategi pembelajaran Mind Map yang memiliki gaya belajar visual.

\section{PENUTUP}

Berdasarkan hasil penelitian dan pembahasan yang dikemukakan sebelumnya, maka dapat simpulkan bahwa:

1. Hasil belajar menggambar teknik 1 siswa yang diajarkan dengan Strategi Mind Map lebih tinggi dibandingkan dengan hasil belajar menggambar teknik 1 siswa yang diajarkan dengan Strategi pembelajaran ekspositori.

2. Hasil belajar menggambar teknik 1 siswa yang memiliki gaya berpikir sekuensial konkrit lebih tinggi daripada siswa yang memiliki gaya berpikir sekuensial abstrak.

3. Terdapat interaksi antara Strategi pembelajaran dan gaya berpikir yang memberikan perbedaan pengaruh terhadap hasil belajar menggambar teknik 1 siswa. Perbedaan pengaruh tersebut adalah:

a. Hasil belajar menggambar teknik 1 siswa dengan gaya berpikir sekuensial konkrit yang diajar dengan Strategi Mind Map lebih tinggi daripada hasil belajar siswa dengan Strategi pembelajaran ekspositori

b. Hasil belajar menggambar teknik 1 siswa dengan gaya berpikir sekuensial konkrit yang diajar dengan Strategi Mind Map lebih tinggi daripada hasil belajar siswa dengan gaya berpikir sekuensial abstrak yang diajar dengan Strategi pembelajaran ekspositori

c. Hasil belajar menggambar teknik 1 siswa dengan gaya berpikir sekuensial konkrit yang diajar dengan Strategi pembelajaran ekspositori lebih rendah daripada hasil belajar siswa dengan gaya berpikir sekuensial abstrak yang diajar dengan Strategi pembelajaran ekspositori.

d. Hasil belajar menggambar teknik 1 siswa dengan gaya berpikir sekuensial abstrak yang diajar dengan Strategi Mind Map lebih rendah daripada hasil belajar siswa dengan gaya berpikir sekuensial abstrak yang diajar dengan Strategi pembelajaran ekspositori

e. Hasil belajar menggambar teknik 1 siswa yang diajar dengan Strategi Mind Map lebih tinggi daripada hasil belajar siswa yang diajar dengan Strategi pembelajaran ekspositori.

f. Hasil belajar menggambar teknik 1 siswa dengan gaya berpikir sekuensial konkrit lebih tinggi daripada hasil belajar siswa dengan kemampuan gaya berpikir sekuensial abstrak.

\section{DAFTAR PUSTAKA}

Aris Munandar. 1999. Pendidian Bagi Pengembangan Sumber Daya Manusia. Jakarta : PT. Gramedia

Anderson, O.W. dan Krathwohl, D.R. 2001. Taxonomy for Learning, Teaching, and Assessing. New York: Addison Wesley Longman, Inc.

Arends, R. 2008. Learning to Teach. Yogjakarta: Pustaka Pelajar.

Ary, D. Jacobs, L.C Razavieh, A. (1982). Pengantar Penelitian Dalam Pendidikan. (Penerjemah Furcham, A). Surabaya: Usaha Nasional.

Bobbi DePorter, Dkk.2000. Quantum Learning . Bandung : Penerbit Kaifa.

Bobbi DePorter, Dkk.2003. Quantum Learning. Bandung: Penerbit Kaifa.

Bobbi DePorter, Dkk .2007. Quantum Teaching. Bandung: Penerbit Kaifa.

Djamarah, Saiful. 2006. Strategi Belajar Mengajar. Jakarta: Rineka Cipta.

Dahar, Ratna Wilis. 1989. Teori-Teori Belajar. Bandung : PT. Gelora Aksara Pratama. 
Dick, W. \& Carey, L. 2005. The Systematic Design of Instruction. Glenview, Illinois: Scoot, Foresman and Company.

Frick, Heinz. 2003. Ilmu Konstruksi Stuktur Bangunan. Yogyakarta: Kanisius

Gagne, R. M. 1977. The Condition of Learning. New York: Halt Rinerhart and Winston.

Gerlach and Elly. 1980. Teaching and Media Asystematic Approach. Englewood Cliffs, N.J.

Gunawan A.W. 2007. Born to be A Genius. Jakarta: Gramedia Pustaka.

Hernowo. 2004. Vitamin T: Bagaimana Mengubah Diri Lewat Membaca dan Menulis. Bandung: Mizan Learning Center.

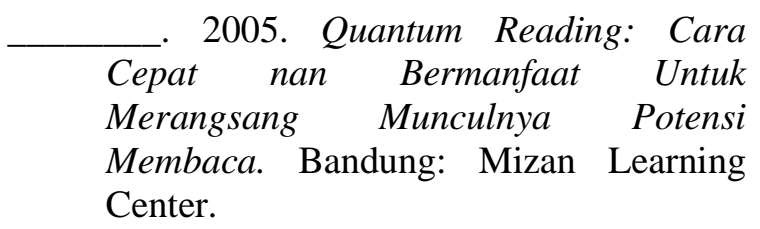

Juhana 0, Suratman M. 2000. "Menggambar Teknik Mesin”. Bandung: Pustaka Grafika.

Lassei. 1986. The Great of Brain. New York: Macmillan Company.

Lazzader. 2003. Menggambar Teknik Dasar. Jakarta: PT. Gramedia

Munandar, Utami. 1998. Memupuk Bakat dan Kreativitas Siswa Sekolah Menengah. Jakarta: PT. Gramedia

Nawawi, Hadari. 1995. Penelitian Terapan. Yogyakarta: Fakultas Psikologi Universitas Gajah Mada.

Nasoetion, N. dan Suryanto. A. Tes, Pengukuran, dan Penilaian. Jakarta: Pusat Penerbitan UT. 2002.

Nasution, S. 2005. Berbagai Pendekatan Dalam Proses Belajar dan Mengajar. Jakarta : Bumi Aksara.

Nurhadi. 2003. Contextual Teaching and Learning. Jakarta: Depdikbud Dirjen Dikti.

Prawiradilaga, D.S. 2007. Prinsip Desain Pembelajaran. Jakarta: Kencana

Rakhmat, Jalaluddin. 2006. Belajar Cerdas. Bandung: Mizan Learning Center.

Sanjaya, Wina. 2009. Strategi Pembelajaran Berorientasi Standar Proses Pendidikan. Jakarta : Kencana Prenada Media Group

Sato G.T., Hartanto N.S. 1981. "Menggambar Teknik Mesin Menurut Standar ISO". Pradnya Paramita.

Shindunata. 2000. Mengagas Paradigma Baru Pendidikan. Jakarta : Kanisius.
Soemanty, Wasty, 1984, Psikologi Pendidikan. Jakarta : Bina Aksara

Seels, B.B \& Richey. 1994. Instructional Technology: The Defenition and Domain of Field. Washington, DC: AECT.

Suparyono Y. 1981. "Konstruksi Perspektif". Yogyakarta: Kanisius.

Suryosubroto, B. 2009. Proses Belajar Mengajar Disekolah. Jakarta: Rineka Cipta.

Snelbecker, G. 1974. Learning Theory, Instructiona Theory, and

Psychoeducational Design. New York: McGraw-Hill Book Company.

Sudjana, N. 1998. Penilaian Hasil Proses Belajar. Bandung: Remaja Rosdakarya.

Tan, O.S. 2004. Students' experiences in problem-based learning: Three Blind Innovations in Education and Teaching International. Singapore: Thomson Learning.

Tilaar, H.A.R. 1999. Beberapa Agenda Reformasi Pendidikan Nasional Dalam Perspektif Abad 21. Magelang: Tera Indonesia.

Uno, H. 2008. Perencanaan Pembelajaran. Jakarta: Bumi Aksara.

Usman, Oetoyo. 1989. Proses Belajar Mengajar di Kelas. Bandung: Remaja Karya

Usman, Uzer. 1997. Interaksi Pendidikan di Sekolah Menengah. Jakarta: PT. Gramedia

Winkel, W. S. 2007. Psikologi Pengajaran. Yogyakarta: Media Abadi.

Wena,M. 2009. Strategi Pembelajaran Inovatif Kontemporer. Jakarta: Bumi Aksara.

Titus. 1952. Living Issues in Philosophy, New York: American book Company

Windura, Sutanto. 2008. Mind Map Langkah Demi Langkah. Jakarta : Elex Media Komputindo 